\title{
Effects of injection of hydrolysis plasma protein solution on the antioxidant properties in porcine M. Longissimus Lumborum
}

Hyun-Woo Seo ${ }^{1}$, Jin-Kyu Seo ${ }^{2}$ and Han-Sul Yang ${ }^{2^{*}}$

\begin{abstract}
Background: Plasma protein hydrolysates have been shown to possess antioxidant activity. However, no report has yet to examine the antioxidant effects of injection of plasma protein hydrolysates on meat quality. Therefore, in this study, the effects of injection of hydrolysis plasma protein solution on meat quality and storability were investigated in porcine M. longissimus lumborum.

Methods: Twelve pigs were randomly selected at a commercial slaughter plant and harvested. Dissected loins were injected with one of five solutions: C- control (untreated), T1- $10 \mathrm{mM}$ phosphate buffer solution (PBS), T2- $10 \mathrm{mM}$ PBS with $0.01 \%$ butylated hydroxytoluene, T3- 10 mM PBS with $5 \%$ plasma proteins, and T4- 10 mM PBS with $5 \%$ hydrolysis plasma proteins.

Results: $\mathrm{T3}$ and $\mathrm{T} 4$ induced greater reduction in protein content of the loin muscle than other treatments. $\mathrm{T} 2$ resulted in the lowest pH as well as highest cooking loss. After a storage period of 3-7 days, both lightness and redness of meat were unaffected by all injection treatments. However, yellowness was significantly elevated by treatment with T4 relative to the control. T4 also resulted in the lowest shear force (a measure of meat toughness), suggesting improvement of texture or tenderness. Further, T4 resulted in the most stable TBARS values during storage, indicating that this treatment might retard rancidity in meat.
\end{abstract}

Conclusion: Injection of porcine M. longissimus lumborum with hydrolysis plasma protein solution could improve overall pork quality, including tenderness and storability.

Keywords: Hydrolysis plasma proteins, Shear force, Lipid peroxidation, Meat quality

\section{Background}

Addition of marinade solutions to pork and other meat products to enhance quality is a well-established practice in many countries $[1,2]$. A combination of salt and phosphate is commonly used to induce synergistic effects in meat tissue [3-5]. This procedure not only improves juiciness and tenderness but also increases the weight of the saleable product, caused by the retention of added water. The concentration of the additive needs

\footnotetext{
* Correspondence: hsyang@gnu.ac.kr

2Division of Applied Life Science Graduate School (BK21 plus), Institute of Agriculture and Life Science, Gyeongsang National University, Jinju 52828, South Korea

Full list of author information is available at the end of the article
}

to be such that tenderness and juiciness are improved but flavor and color are not adversely affected and the meat is not over-tenderized. The mechanism responsible for increased tenderness and juiciness is linked to increased water retention, and consequent swelling, of myofibrils in the meat [6].

The relative efficiency of marination for improving juiciness and tenderness in meat has been established based on sensory evaluation [7]. In a prior study, Killefer [8] injected pork loins $1 \mathrm{~h}$ after the animal was slaughtered with a solution of citrate, phosphate, and salt or a solution of only phosphate and salt (control). In their results, increased ultimate $\mathrm{pH}$ values, improved color, and decreased cooking loss and shear force values were 
reported for the treated meat compared to the controls. Sodium citrate has been used as a glycolytic inhibitor in beef muscle to improve tenderness [9]. It has been hypothesized that the $\mathrm{pH}$ increase resulting from glycolytic inhibition creates an environment in which protein-denaturing calpains are likely more active. Phosphate injection was originally developed to reduce the the sodium content of processed meats such as ham but has been gradually incorporated into fresh meats as well in order to improve their tenderness and juiciness [10]. Phosphate 'enhancement' is now commonly used in the pork industry to increase $\mathrm{pH}$ and improve pork quality attributes. Although phosphate injection may increase saltiness and decrease the shelf life of meat [11], routine use of this method in industry necessitates its inclusion in a study that compares various new technologies for improving pork quality.

The most common synthetic antioxidants, such as butylated hydroxyanisole (BHA) and butylated hydroxytoluene (BHT), have been widely used for many years to delay lipid oxidation and extend shelf-life of meat [12]. However, concerns about the long-term safety and negative consumer perception of synthetic antioxidants have led to an increasing demand for natural antioxidants in meat and meat products [13]. It has been reported that some protein and enzymatic hydrolysates of meat and meat by-products exert antioxidant effects in food systems [14]. For instance, plasma protein hydrolysates have been shown to possess antioxidant activity [15]. However, no information on the effect of injection of antioxidants on meat quality has been published.

Therefore, the purpose of this study was to investigate the effects of plasma protein injection into pre-rigor porcine $M$. longissimus lumborum on ultimate pork quality characteristics such as color, muscle $\mathrm{pH}$, shear force, protein solubility, and rancidity during cold storage.

\section{Methods}

\section{Preparation of non-hydrolysis and hydrolysis bovine plasma protein}

To prepare plasma proteins (PP), from cattle blood plasma, $0.5 \mathrm{~N}$ ethylenediaminetetraacetic acid (EDTA) as an anticoagulated was added to fresh cattle blood at a ratio 1:9 (v/v), mixed well, and placed immediately on ice for $30 \mathrm{~min}$. Samples were centrifuged by a refrigeration centrifuge (SUPRA $25 \mathrm{~K}$, Hanil Science, Korea) at 14,000 $\mathrm{g}$ for $15 \mathrm{~min}$ at $4{ }^{\circ} \mathrm{C}$. The plasma powders were freeze-dried (Clean van 8B Freeze-Dryer, BioTron, Inc., Korea), pulverized, placed in sealed bags, and stored at $4{ }^{\circ} \mathrm{C}$.

To prepare plasma protein hydrolysate (PPH), $\mathrm{PP}$ solution [5\% w/v $10 \mathrm{mM}$ sodium phosphate buffer ( $\mathrm{pH} 7.0)$ ] was heat-pretreated $\left(90{ }^{\circ} \mathrm{C}, 5 \mathrm{~min}\right)$ and then hydrolyzed with Alcalase. The enzyme to substrate ratio $(E / S)$ was 2:100 (g/g). The $\mathrm{pH}$ of PP solution was adjusted to the optimal value for Alcalase ( $\mathrm{pH}$ 8.32) before hydrolysis and was readjusted to the optimal value with $1 \mathrm{M} \mathrm{NaOH}$ every 15 min during hydrolysis. Hydrolysates were produced by varying the hydrolyzed time to $338 \mathrm{~min}$ and hydrolyzed temperature $54{ }^{\circ} \mathrm{C}$. After hydrolysis, the $\mathrm{pH}$ of the solution was brought to 7.0 and the solution was then heated at $95{ }^{\circ} \mathrm{C}$ for $5 \mathrm{~min}$ to inactivate the enzyme. Degree hydrolysis $(\mathrm{DH})$ was determined by assaying free amino groups with 2, 4, 6-trinitrobenzenesulfonic acid (TNBS) according to Alder-Nissen [16]. The DH of hydrolyzed PP was $18.8 \%$.

\section{Preparation of samples}

Approximately $50 \mathrm{~min}$ post-mortem, dissected loins were assigned to injection treatments as follows: $\mathrm{C}$ - control (untreated), T1- $10 \mathrm{mM}$ phosphate buffer solution (PBS) (pH 7.0), T2- $10 \mathrm{mM}$ PBS with $0.01 \%$ butylated hydroxytoluene (BHT), T3- $10 \mathrm{mM}$ PBS with $5 \%$ plasma proteins, and T4 $10 \mathrm{mM}$ PBS with $5 \%$ hydrolysis plasma proteins. Before injection, skin was sliced perpendicular to the length of the loin, at approximately $3-\mathrm{cm}$ intervals, in order to allow the injection needle to penetrate the muscle. Solutions were injected at room temperature. A handheld injector and $10-\mathrm{cm}$ needles were used to inject the experimental solutions. After injection, pump percentage was calculated. It was assumed that the loin constituted $10 \%$ of the total weight of the side, and absorbed all of the injected solution. Pigs were stunned by using both an electric stunning wand and a captive bolt stunner. after stunning, pigs were exsanguinated and harvested according to normal procedures; the procedure was approved by the institutional Animal Care and Use Committee. After the carcasses and washed, each side was weighed.

\section{Proximate chemical composition analysis}

The proximate chemical compositions of the marinated samples were determined following standard procedures prescribed by the Association of Official Analytical Chemists [17]. Moisture, crude protein, fat, and ash contents were determined using the oven, Folch et al. [18], Kjedahl, and dry ashing methods, respectively.

\section{$\mathrm{pH}$ measurement}

Approximately $3 \mathrm{~g}$ of each meat sample were weighed out, and distilled water was added. A slurry was made out of the meat and distilled water using a homogenizer (Ultra Turrax T25D, IKA, Germany). The pH of each slurry sample was measured, in triplicate, using a digital pH meter (MP230, Mettler Toledo, Switzerland).

\section{Cooking loss}

Weights of the uncooked and cooked samples were recorded (as per Boles and Swan, [19]), and cooking yield was calculated as follows: 
Cooking loss $(\%)=($ cooked weight $/$ uncooked weight $) \times 100$

Loss due to cooking was determined.

\section{Color evaluation}

The internal color (International Commission on Illumination L" (lightness), a" (redness), and b" (yellowness)) of the injected porcine $M$. longissimus lumborum samples were measured using a Minolta Chromameter (Minolta CR 301, Tokyo, Japan) and standardized with a white calibration plate $(Y=93.5 ; x=0.3132 ; y=0.3198)$. Internal color was measured at three random locations of the sample surface, and the mean of these values was used in statistical analyses.

\section{Myoglobin content measurement}

The concentration of myoglobin forms was determined according to the method described by Krzywicki [20]. Myoglobin was extracted from meat samples using phosphate buffer with a pH of 6.8 and ionic strength of 0.04 . The final ratio of buffer to meat in the extracts was 5:1. The absorbance levels of the extract at four wavelengths $(572,565$, 545 , and $525 \mathrm{~nm}$ ) was measured using a spectrophotometer (8453 UV-visible Agilent Co. U.S.A.) The linear relationship between absorbance and myoglobin concentration was checked for all wavelengths used. The concentration of myoglobin forms (MetMb) was calculated as

$$
\text { MetMb }=-2.514 \mathrm{R}_{1}+0.777 \mathrm{R}_{2}+0.800 \mathrm{R}_{3}+1.098
$$

where $R_{1}, R 2$, and $R 3$ are the absorbance ratios $A_{572} /$ $A_{525}, A_{565} / A_{525}$, and $A_{545} / A_{525}$ respectively.

\section{Protein solubility measurement}

In order to determine the solubility of sarcoplasmic and total (sarcoplasmic + myofibrillar) proteins, two extractions were conducted. First, sarcoplasmic proteins were extracted with $10 \mathrm{~mL}$ of ice-cold $25 \mathrm{mM}$ potassium phosphate buffer $(p H=7.2)$, which was added to each of the quadruplicate 1-g muscle samples [21]. The samples were then cut up with scissors, homogenized on ice using a Polytron on the lowest setting $(3 \times 4$-second bursts to minimize protein denaturation through heating), and left on a shaker at $4{ }^{\circ} \mathrm{C}$ overnight. Next, the samples were centrifuged at $1,500 \times g$ for $20 \mathrm{~min}$ and the protein concentrations of the supernatants were determined by the biuret method, using bovine serum albumin as the standard. Second, total protein was extracted with $20 \mathrm{~mL}$ of ice-cold $1.1 \mathrm{M}$ potassium iodide solution in a $0.1 \mathrm{M}$ phosphate buffer $(p H=7.2)$ which was added to duplicate $1 \mathrm{~g}$ samples. Homogenization, shaking, centrifugation, and protein determination of the samples were performed as described for sarcoplasmic proteins. Myofibrillar protein concentration was calculated as the difference between total and sarcoplasmic protein concentrations.

\section{Shear force analysis}

Cooked meat samples were allowed to cool to $25^{\circ} \mathrm{C}$, after which three $1.27 \mathrm{~cm}$ core samples, oriented parallel to the muscle fiber structure of the meat, were excised. WarnerBraztler shear force, perpendicular to the muscle fiber orientation, was determined for each core using an Instron Universal Testing Machine (Model 1000) with a load cell of $50 \mathrm{~kg}$ and a chart speed of $100 \mathrm{~mm} / \mathrm{min}$.

\section{Lipid oxidation}

The thiobarbituric acid-reactive substance (TBARS) contents of the samples, from each treatment, were determined using the TBA distillation procedure modified by Burge and Aust [22]. Five-gram samples were weighed and homogenized using a homogenizer (Ultra Turrax T25D, IKA, Germany). The homogenate of the samples was transferred to a disposable test tube, into which $10 \%$ butylated hydroxyanisole, and thiobarbituric acid/trichloroacetic acid (TBA/TCA) solution were added. The sample was mixed using a vortex mixer, and then incubated in a boiling water bath for the development of color. After cooling, supernatant solution was determined at $531 \mathrm{~nm}$. The TBARS values were expressed as the number of milligrams of malondialdehyde per kilogram of sample.

\section{Statistical analysis}

Data were analyzed by ANOVA test and Duncan's multiple comparison was applied to test the significance of differences between groups. Statistical Analysis Systems (SAS, [23]) was used for analyzing data.

\section{Results and Discussion}

\section{Proximate chemical composition analysis}

Injection of hydrolysis plasma proteins (T4) and simple plasma proteins (T3) decreased the protein contents of the treated samples $(p<0.05$; Table 1$)$. However, injection of plasma proteins into porcine M. longissimus lumborum tissue had no effect on fat and ash contents of the samples. The achieved injection gains were close to

Table 1 Effects of injection with plasma protein solution on proximate composition (\%) in porcine longissimus muscle

\begin{tabular}{lllll}
\hline Treatments $^{1)}$ & Moisture (\%) & Fat (\%) & Protein (\%) & Ash (\%) \\
\hline C & $71.82 \pm 0.34^{\mathrm{C}}$ & $4.85 \pm 0.37$ & $19.78 \pm 0.10^{\mathrm{A}}$ & $1.03 \pm 0.01$ \\
T1 & $74.22 \pm 0.45^{\mathrm{B}}$ & $4.37 \pm 0.30$ & $19.73 \pm 0.10^{\mathrm{A}}$ & $1.02 \pm 0.04$ \\
T2 & $75.35 \pm 0.34^{\mathrm{A}}$ & $4.95 \pm 0.08$ & $19.38 \pm 0.32^{\mathrm{A}}$ & $1.06 \pm 0.04$ \\
T3 & $73.95 \pm 0.29^{\mathrm{B}}$ & $4.91 \pm 0.24$ & $18.45 \pm 0.21^{\mathrm{B}}$ & $1.06 \pm 0.02$ \\
T4 & $75.17 \pm 0.15^{\mathrm{A}}$ & $4.81 \pm 0.22$ & $17.38 \pm 0.01^{\mathrm{C}}$ & $1.06 \pm 0.02$
\end{tabular}

$\overline{\mathrm{A}-\mathrm{C}}$ Means with different superscripts in the same column significantly differ at $p<0.05$

${ }^{1} \mathrm{C}$-control, T1-injection with $10 \mathrm{mM}$ sodium phosphate buffer $(\mathrm{pH}=7.0)$ at $10 \%$, T2-injection with $10 \mathrm{mM}$ sodium phosphate buffer $(\mathrm{pH} 7.0)$ with $0.01 \%$ BHT at $10 \%$, T3-injection with $10 \mathrm{mM}$ sodium phosphate buffer $(\mathrm{pH}$ 7.0) with $5 \%$ plasma protein at $10 \%$, and T4-injection with $10 \mathrm{mM}$ sodium phosphate buffer $(\mathrm{pH} 7.0$ ) with $5 \%$ hydrolysis plasma protein at $10 \%$ 
the target value of $10 \%$ of muscle weight, likely due to significant increases in moisture contents of the samples in response to all treatments $(p<0.05$; Table 1$)$.

\section{$\mathrm{pH}$ and cooking loss}

The $\mathrm{pH}$ values of $\mathrm{T} 1, \mathrm{~T} 2$, and $\mathrm{T} 3$ were significantly lower than those of T4 and the control $(p<0.05$; Table 2). However, during cold storage, samples injected with the hydrolysis and non-hydrolysis plasma protein solutions (T3 and T4) showed decreased $\mathrm{pH}$ values $(p<0.05)$. Contrary to our findings, $\mathrm{pH}$ has been shown to increase in samples treated with phosphate and bicarbonate [5, 24, 25].

Quantification of expressible moisture (EM), a measure of the water-holding capacity (WHC) of meat, involves the use of force to expel water from the meat $[26,27]$. Therefore, lower EM values coincide with increased breaking force values [28]. Myofibrillar proteins, myosin, actin, and, to some extent, tropomyosin are the main water-binding components of muscular tissue [27]. Denatured or precipitated sarcoplasmic proteins bound to myofibrils play an important role in decreasing the WHC of meat $[27,28]$.

Cooking loss of samples treated with the experimental solutions was significantly $(p<0.05)$ higher than those of samples treated with the control, during cold storage (Table 2). Improvements in WHC, observed in meat treated with sodium bicarbonate, may be attributed to increases in muscle $\mathrm{pH}$ and ionic strength [29]. Ionic strength may be related to the amount of ions in solution; sodium bicarbonate increases the number of ions,

Table 2 Effects of injection with plasma protein solution on $\mathrm{pH}$ and cooking loss (\%) in porcine longissimus muscle, during cold storage

\begin{tabular}{|c|c|c|c|c|}
\hline \multicolumn{2}{|l|}{ Treatments ${ }^{1)}$} & \multicolumn{3}{|l|}{ Storage (days) } \\
\hline & & $\overline{1}$ & 3 & 7 \\
\hline \multirow[t]{5}{*}{$\overline{\mathrm{pH}}$} & $C$ & $5.67 \pm 0.02^{\mathrm{Aa}}$ & $5.68 \pm 0.02^{\mathrm{Aa}}$ & $5.64 \pm 0.01^{\mathrm{Ab}}$ \\
\hline & $\mathrm{T} 1$ & $5.54 \pm 0.04^{B}$ & $5.53 \pm 0.03^{B}$ & $5.48 \pm 0.02^{\mathrm{B}}$ \\
\hline & $\mathrm{T} 2$ & $5.45 \pm 0.02^{C}$ & $5.47 \pm 0.01^{C}$ & $5.42 \pm 0.05^{C}$ \\
\hline & T3 & $5.54 \pm 0.01^{\mathrm{Ba}}$ & $5.45 \pm 0.01^{\mathrm{Cb}}$ & $5.46 \pm 0.01^{\mathrm{BCb}}$ \\
\hline & $\mathrm{T} 4$ & $5.69 \pm 0.03^{\mathrm{Aa}}$ & $5.71 \pm 0.02^{\mathrm{Aa}}$ & $5.63 \pm 0.01^{\mathrm{Ab}}$ \\
\hline \multirow[t]{5}{*}{ Cooking loss (\%) } & C & $40.21 \pm 0.26^{\mathrm{Ca}}$ & $38.22 \pm 0.14^{B C}$ & $38.95 \pm 0.82^{\mathrm{Bab}}$ \\
\hline & $\mathrm{T} 1$ & $46.91 \pm 1.64^{\mathrm{A}}$ & $43.65 \pm 0.48^{A}$ & $41.72 \pm 2.26^{\mathrm{AB}}$ \\
\hline & $\mathrm{T} 2$ & $45.96 \pm 1.64^{\mathrm{AB}}$ & $44.13 \pm 0.35^{A}$ & $44.00 \pm 0.86^{A}$ \\
\hline & T3 & $41.75 \pm 2.17^{B C}$ & $39.25 \pm 2.64^{B}$ & $40.95 \pm 0.26^{\mathrm{AB}}$ \\
\hline & $\mathrm{T} 4$ & $41.89 \pm 2.68^{B C}$ & $43.41 \pm 1.67^{A}$ & $42.19 \pm 0.91^{\mathrm{AB}}$ \\
\hline \multicolumn{5}{|c|}{$\begin{array}{l}\text { A-C Means with different superscripts in the same column significantly differ } \\
\text { at } p<0.05 \\
\text { a-c } M \text { Means with different superscripts in the same row significantly differ } \\
\text { at } p<0.05 \\
{ }^{1} \mathrm{C} \text {-control, T1-injection with } 10 \mathrm{mM} \text { sodium phosphate buffer ( } p H \text { H.0) at } 10 \% \text {, } \\
\text { T2-injection with } 10 \mathrm{mM} \text { sodium phosphate buffer }(\mathrm{pH}=7.0) \text { and } 0.01 \% \mathrm{BHT} \\
\text { at } 10 \% \text {, T3-injection with } 10 \mathrm{mM} \text { sodium phosphate buffer }(p H=7.0) \text { and } 5 \% \\
\text { plasma protein at } 10 \% \text {, and T4-injection with } 10 \mathrm{mM} \text { sodium phosphate buffer } \\
(p H=7.0) \text { and } 5 \% \text { hydrolysis plasma protein at } 10 \%\end{array}$} \\
\hline
\end{tabular}

which react with proteins, as well as hydration. However, the treatments in this study failed to improve the WHC of the meat samples. During cold storage, cooking loss of samples injected with the hydrolysis and non-hydrolysis plasma protein solutions was lower than those of samples treated with BHT solution.

\section{Color}

After 1 day, the lightness and redness of meat injected with plasma protein solution were higher than those of meat injected with hydrolysis plasma protein solution. Yellowness induced by the treatments significantly decreased $(p<0.05)$ with storage time, although this decrease was not observed in meat treated with the control solution. During cold storage, the yellowness of meat injected with hydrolysis plasma protein solution was significantly higher than that of meat injected with the other solutions $(p<0.05$; Table 3$)$.

This color change in pork loin was expected based on a previously established strong positive relationship between color of pork and $\mathrm{pH}[30,31]$. PSE and DFD pork differ from normal pork in terms of physiological and biochemical characteristics. The unusual $\mathrm{pH}$ and WHC of the PSE and DFD muscles lead to unusual meat colors [32]. In this study, the effects of hydrolysis plasma

Table 3 Effects of injection with plasma protein solution on CIE $L^{*}, a^{*}$, and $b^{*}$ in porcine longissimus muscle, during cold storage

\begin{tabular}{|c|c|c|c|c|}
\hline \multirow[t]{2}{*}{ Treatments $^{1)}$} & & \multicolumn{3}{|l|}{ Storage (days) } \\
\hline & & 1 & 3 & 7 \\
\hline \multirow[t]{5}{*}{$L^{*}$ (lightness) } & $C$ & $58.29 \pm 3.02^{\mathrm{AB}}$ & $57.84 \pm 2.86$ & $57.65 \pm 1.54$ \\
\hline & $\mathrm{T} 1$ & $58.39 \pm 2.01^{A B}$ & $58.90 \pm 3.56$ & $58.42 \pm 2.63$ \\
\hline & $\mathrm{T} 2$ & $56.53 \pm 3.11^{B}$ & $56.46 \pm 3.86$ & $56.91 \pm 2.60$ \\
\hline & $\mathrm{T} 3$ & $60.04 \pm 0.87^{A}$ & $56.88 \pm 3.22$ & $57.22 \pm 2.48$ \\
\hline & $\mathrm{T} 4$ & $58.18 \pm 2.32^{\mathrm{AB}}$ & $59.89 \pm 3.72$ & $57.94 \pm 4.95$ \\
\hline \multirow[t]{5}{*}{$a^{*}$ (redness) } & C & $7.77 \pm 0.78^{\mathrm{BC}}$ & $7.46 \pm 0.54$ & $7.32 \pm 0.79$ \\
\hline & $\mathrm{T} 1$ & $8.56 \pm 0.46^{\mathrm{ABa}}$ & $7.60 \pm 1.12^{\mathrm{ab}}$ & $6.93 \pm 0.90^{b}$ \\
\hline & $\mathrm{T} 2$ & $8.95 \pm 1.04^{\mathrm{Aa}}$ & $7.25 \pm 1.10^{b}$ & $7.20 \pm 0.55^{b}$ \\
\hline & $\mathrm{T} 3$ & $7.33 \pm 0.54^{C}$ & $7.07 \pm 1.38$ & $6.46 \pm 0.89$ \\
\hline & $\mathrm{T} 4$ & $8.40 \pm 0.49^{A B}$ & $7.43 \pm 0.93$ & $7.44 \pm 1.41$ \\
\hline \multirow[t]{5}{*}{$b^{*}$ (yellowness) } & C & $6.68 \pm 1.20^{c}$ & $7.35 \pm 0.68^{B}$ & $6.65 \pm 0.65^{B}$ \\
\hline & $\mathrm{T} 1$ & $7.88 \pm 0.38^{\mathrm{ABa}}$ & $7.30 \pm 0.77^{\mathrm{Bab}}$ & $6.60 \pm 0.50^{\mathrm{Bb}}$ \\
\hline & $\mathrm{T} 2$ & $7.77 \pm 0.27^{\mathrm{ABa}}$ & $6.49 \pm 0.36^{\mathrm{Cb}}$ & $6.50 \pm 0.40^{\mathrm{Bb}}$ \\
\hline & $\mathrm{T} 3$ & $7.10 \pm 0.64^{\mathrm{BCa}}$ & $6.85 \pm 0.42^{\mathrm{BCa}}$ & $5.93 \pm 0.60^{\mathrm{Bb}}$ \\
\hline & $\mathrm{T} 4$ & $8.46 \pm 0.18^{\mathrm{Aa}}$ & $8.29 \pm 0.34^{\mathrm{Aa}}$ & $7.61 \pm 0.54^{\mathrm{Ab}}$ \\
\hline
\end{tabular}

$\overline{\mathrm{A}-\mathrm{C}}$ Means with different superscripts in the same column significantly differ at $p<0.05$

${ }^{a-b}$ Means with different superscripts in the same row significantly differ at $p<0.05$

${ }^{1} \mathrm{C}$-control, T1-injection with $10 \mathrm{mM}$ sodium phosphate buffer $(\mathrm{pH}=7.0)$ at $10 \%$, T2-injection with $10 \mathrm{mM}$ sodium phosphate buffer $(\mathrm{pH}=7.0)$ and $0.01 \%$ BHT at $10 \%$, T3-injection with $10 \mathrm{mM}$ sodium phosphate buffer $(\mathrm{pH}=7.0)$ with $5 \%$ plasma protein at $10 \%$, and T4-injection with $10 \mathrm{mM}$ sodium phosphate buffer $(\mathrm{pH}=7.0)$ and $5 \%$ hydrolysis plasma protein at $10 \%$ 
protein solution injection on muscle $\mathrm{pH}$ were dramatic. As the ultimate $\mathrm{pH}$ level of the plasma protein solution treated samples was not significantly different (Table 2), the higher $\mathrm{a}^{*}$ and $\mathrm{b}^{*}$ values can be directly attributed to the injection of hydrolysis plasma protein into pork.

Meat color is one of the most important factors influencing the quality and consumer preferences related to meat, and is considered as an indicator of meat freshness and 'doneness' (i.e., how well a meat is cooked) [33]. In measuring bloom on the surface of muscles, Brewer et al. [34] reported that the $\mathrm{L}^{\prime \prime}, \mathrm{a}^{\prime \prime}$, and $\mathrm{b}$ " values were most correlated to the visual determination of muscle surface pinkness $(r=-0.67$ to -0.80$)$. Lindahl et al. [35] reported that heme pigment and metmyoglobin contents are only slightly correlated with peak $\mathrm{L}^{\prime \prime}$ values $(r=0.35-0.45)$. Furthermore, heme pigment and metmyoglobin contents were less correlated with $\mathrm{b}^{*}$ than with a values $(r=0.40$ and 0.50 , respectively). Generally, changes in $L^{\prime \prime}$ values (lightness) over the period of retail display were very subtle [36]. The oxymyoglobin and myoglobin fractions in meat were found to be the most important factors related to variations in $b^{*}$ values [35]. According to Lindahl et al. [35] observed decreases in $b^{\prime \prime}$ suggest that the color of pork became less yellow because browning reactions (lower ratio of myoglobin to oxymyoglobin) in cooked meat were fewer.

\section{Changes in metmyoglobin (MetMb)}

During cold storage, although the MetMb content (\%) of meat treated with the experimental solutions was lower than that of meat treated with the control, all meat samples showed increased MetMb content (Table 4). Hydrolysis plasma proteins significantly decreased MetMb content (\%) during cold storage. Meat color is influenced by many factors, including the concentration of heme

Table 4 Effects of injection with plasma protein solution on metmyoglobin percentage of porcine longissimus muscle, during cold storage

\begin{tabular}{|c|c|c|c|}
\hline \multirow[t]{2}{*}{ Treatments ${ }^{1)}$} & \multicolumn{3}{|l|}{ Storage (days) } \\
\hline & 1 & 3 & 7 \\
\hline$C$ & $4.92 \pm 0.04^{\mathrm{AC}}$ & $7.52 \pm 0.04^{\mathrm{Ab}}$ & $11.54 \pm 0.07^{\mathrm{Aa}}$ \\
\hline T1 & $4.65 \pm 0.07^{B C}$ & $6.60 \pm 0.02^{\mathrm{Bb}}$ & $9.87 \pm 0.03^{\mathrm{Ba}}$ \\
\hline T2 & $4.68 \pm 0.05^{B C}$ & $6.10 \pm 0.03^{\mathrm{Cb}}$ & $8.04 \pm 0.01^{\mathrm{Ca}}$ \\
\hline T3 & $4.78 \pm 0.02^{B C}$ & $6.08 \pm 0.01^{\mathrm{cb}}$ & $8.03 \pm 0.02^{\mathrm{Ca}}$ \\
\hline$\Gamma 4$ & $4.71 \pm 0.03^{B C}$ & $5.99 \pm 0.03^{\mathrm{Db}}$ & $7.31 \pm 0.05^{\mathrm{Da}}$ \\
\hline \multicolumn{4}{|c|}{$\begin{array}{l}\text { A-C Means with different superscript in the same column significantly differ } \\
\text { at } p<0.05 \\
\text { a-c } M \text { Means with different superscript in the same row significantly differ } \\
\text { at } p<0.05 \\
{ }^{1} \mathrm{C} \text {-control, T1-injection with } 10 \mathrm{mM} \text { sodium phosphate buffer }(p H=7.0) \text { at } \\
10 \% \text {, T2-injection with } 10 \mathrm{mM} \text { sodium phosphate buffer }(p H=7.0) \text { and } 0.01 \% \\
\text { BHT at } 10 \% \text {, T3-injection with } 10 \mathrm{mM} \text { sodium phosphate buffer }(p H=7.0) \text { and } \\
5 \% \text { plasma protein at } 10 \% \text {, and T4-injection with } 10 \mathrm{mM} \text { sodium phosphate } \\
\text { buffer }(p H=7.0) \text { and } 5 \% \text { hydrolysis plasma protein at } 10 \%\end{array}$} \\
\hline
\end{tabular}

pigments, chemical state of myoglobin $(\mathrm{Mb})$, and physical characteristics. Of these factors, myoglobin, a sarcoplasmic protein, is primarily responsible for meat color. Myoglobin is a heme protein that exists in three forms deoxy-myoglobin (DexyMb), oxy-myoglobin (OxyMb), and MetMb [37]). Upon exposure to air, Mb combines with oxygen to form ferrous OxyMb, which is bright red in color; this bright red color is generally interpreted by consumers as an indication of the freshness of meat. However, extended contact of $\mathrm{Mb}$ with oxygen leads to the formation of the oxidized form, ferric MetMb, which is brown and unattractive. During cold storage, the rate of MetMb accumulation on the surface of meat is governed by many intrinsic factors (e.g., $\mathrm{pH}$, muscle metabolic type, animal age, breed, sex, and diet), extrinsic factors (e.g., temperature, oxygen availability, type of lighting, surface microbial growth, and type of packing) or combinations of the two [38]. It has been widely accepted that beef muscles exhibit a wide range of color stability during cold storage [39]. However, the mechanism by which MetMb accumulation influences color is yet to be fully understood. One proposed mechanism for MetMb accumulation is the simultaneous decrease in a" values [40].

\section{Protein solubility}

Sarcoplasmic protein and total protein solubility values of samples treated with plasma protein were significantly higher than those of samples injected with the control and other treatment solutions $(p<0.05$; Table 5). Sarcoplasmic protein denaturation may function as a more effective indicator of muscle quality (especially color) [41]. Changes in sarcoplasmic protein solubility have also been observed to influence WHC, shear force values, gel formation, and the emulsifying capacity of meat [42, 43]. It is also generally accepted that sarcoplasmic proteins are denatured at temperatures over $40{ }^{\circ} \mathrm{C}$, during various heat treatments [41]. Thus, meat protein solubility is influenced by processing conditions, water content, salt content, heat applications, and changes in $\mathrm{pH}$ [42].

Table 5 Effects of injection with plasma protein solution on protein solubility $(\mathrm{mg} / \mathrm{g})$ in porcine longissimus muscle

\begin{tabular}{|c|c|c|c|}
\hline eati & Total protein & Sarcoplasmic protein & Myofibrillar protein \\
\hline & 37 & $67.52 \pm 1.41^{B}$ & \\
\hline & $208.38 \pm 10.82$ & $65.93 \pm 0.60^{B}$ & $142.45 \pm 11.43^{\mathrm{AB}}$ \\
\hline & 2 & $63.15 \pm 1.04^{C}$ & $154.23 \pm 14.57^{\mathrm{A}}$ \\
\hline & $201.21 \pm 2.38$ & 78.80 & \\
\hline & $210.65 \pm 4.51$ & $67.83 \pm 1.20^{\mathrm{B}}$ & $142.81 \pm 3.30^{\mathrm{AB}}$ \\
\hline \multicolumn{4}{|c|}{$\begin{array}{l}\text { A-C Means with different superscripts in the same column significantly differ } \\
\text { at } p<0.05 \\
{ }^{1} \mathrm{C} \text {-control, T1-injection with } 10 \mathrm{mM} \text { sodium phosphate buffer }(\mathrm{pH}=7.0) \text { at } \\
10 \% \text {, T2-injection with } 10 \mathrm{mM} \text { sodium phosphate buffer }(\mathrm{pH}=7.0) \text { and } 0.01 \% \\
\mathrm{BHT} \text { at } 10 \% \text {, T3-injection with } 10 \mathrm{mM} \text { sodium phosphate buffer }(\mathrm{pH}=7.0) \text { and } \\
5 \% \text { plasma protein at } 10 \% \text {, and T4-injection with } 10 \mathrm{mM} \text { sodium phosphate } \\
\text { buffer }(p H=7.0) \text { and } 5 \% \text { hydrolysis plasma protein at } 10 \%\end{array}$} \\
\hline
\end{tabular}


Table 6 Effects of injection with plasma protein solution on Warner-Bratzler shear force $\left(\mathrm{kg} / \mathrm{cm}^{2}\right)$ in porcine longissimus muscle, during cold storage

\begin{tabular}{llll}
\hline Treatments $^{1)}$ & \multicolumn{3}{l}{ Storage (days) } \\
\cline { 2 - 4 } & 1 & 3 & 7 \\
\hline $\mathrm{C}$ & $2.09 \pm 0.28^{\mathrm{Aa}}$ & $1.61 \pm 0.22^{\mathrm{Cb}}$ & $2.36 \pm 0.42^{\mathrm{Ba}}$ \\
T1 & $2.49 \pm 0.61^{\mathrm{A}}$ & $2.80 \pm 0.25^{\mathrm{A}}$ & $2.91 \pm 0.48^{\mathrm{A}}$ \\
T2 & $2.61 \pm 0.49^{\mathrm{A}}$ & $2.74 \pm 0.19^{\mathrm{A}}$ & $2.53 \pm 0.45^{\mathrm{AB}}$ \\
T3 & $2.25 \pm 0.65^{\mathrm{A}}$ & $2.38 \pm 0.17^{\mathrm{B}}$ & $2.39 \pm 0.36^{\mathrm{B}}$ \\
T4 & $1.46 \pm 0.46^{\mathrm{B}}$ & $1.16 \pm 0.19^{\mathrm{D}}$ & $1.15 \pm 0.20^{\mathrm{C}}$ \\
\hline
\end{tabular}

A-D Means with different superscripts in the same column significantly differ at $p<0.05$

${ }^{a-b}$ Means with different superscripts in the same row significantly differ at $p<0.05$

${ }^{1} \mathrm{C}$-control, T1-injection with $10 \mathrm{mM}$ sodium phosphate buffer $(\mathrm{pH}=7.0)$ at $10 \%$, T2-injection with $10 \mathrm{mM}$ sodium phosphate buffer $(\mathrm{pH}=7.0)$ and $0.01 \%$ BHT at $10 \%$, T3-injection with $10 \mathrm{mM}$ sodium phosphate buffer $(\mathrm{pH}=7.0)$ and $5 \%$ plasma protein at $10 \%$, and T4-injection with $10 \mathrm{mM}$ sodium phosphate buffer $(\mathrm{pH}=7.0)$ and $5 \%$ hydrolysis plasma protein at $10 \%$

Kauffman et al. [29] suggested that the increase in protein solubility observed in their study was likely caused by a reduction of protein denaturation in muscles of halothane-sensitive pigs treated with sodium bicarbonate. The findings of Marta et al. [44] highlight the dependence of myofibrillar and sarcoplasmic protein solubilities on meat quality and $\mathrm{NaCl}$ concentration. Further, an increase in total protein solubility, including sarcoplasmic protein solubility, has been reported to decrease drip loss in pork [31].

\section{Shear force}

During cold storage, the shear force of the sample treated with hydrolysis plasma proteins was significantly lower than those of samples treated with the control and experimental solutions $(p<0.05$; Table 6$)$. Tenderness is a major palatability characteristic of meat. In this study, hydrolysis plasma protein injection was effective in reducing shear force, which is a measure of the toughness of meat. The reduction in shear force can be attributed to the increased water content of the treated meat as well as weakening of its myofibrillar structure. It has been suggested that marination greately improves the tenderness of pork compared to other factors pertaining to the production (e.g. breed and feeding levels) and processing (e.g., chilling rate, hip suspension, and electrical stimulation) of the meat [7]. Lawrence et al. [45] and Baublits et al. [46] reported similar differences in the shear force values of longissimus and triceps brachii steaks which were either untreated and or injected with water. Their findings suggest that mechanical tenderization was not responsible for the improvements in tenderness. According to Yasui et al. [47] this tenderizing effect might be attributed to the fact that polyphosphates promote weakening of the myosin heads to actin cross-bridge, and thus promote dissociation of actomyosin. Our results also suggest that the increased tenderness observed in the treated meat samples is likely due to higher water content and weakened muscle structure.

\section{Lipid oxidation}

During cold storage, the interaction between storage period and type of treatment injection (non-hydrolysis and hydrolysis plasma protein solutions) had a significant effect on TBARS in the porcine longissimus muscle $(p<0.05$; Fig. 1$)$. While there were no differences in TBARS between samples at the beginning of cold storage, samples injected with hydrolysis plasma proteins showed significantly lower TBARS than samples injected with the control or other treatments after 7 days $(p<0.05)$. This decrease in TBARS indicates decreased oxidation during cold storage resulting from hydrolysis plasma protein treatment. The lower TBARS in the porcine longissimus

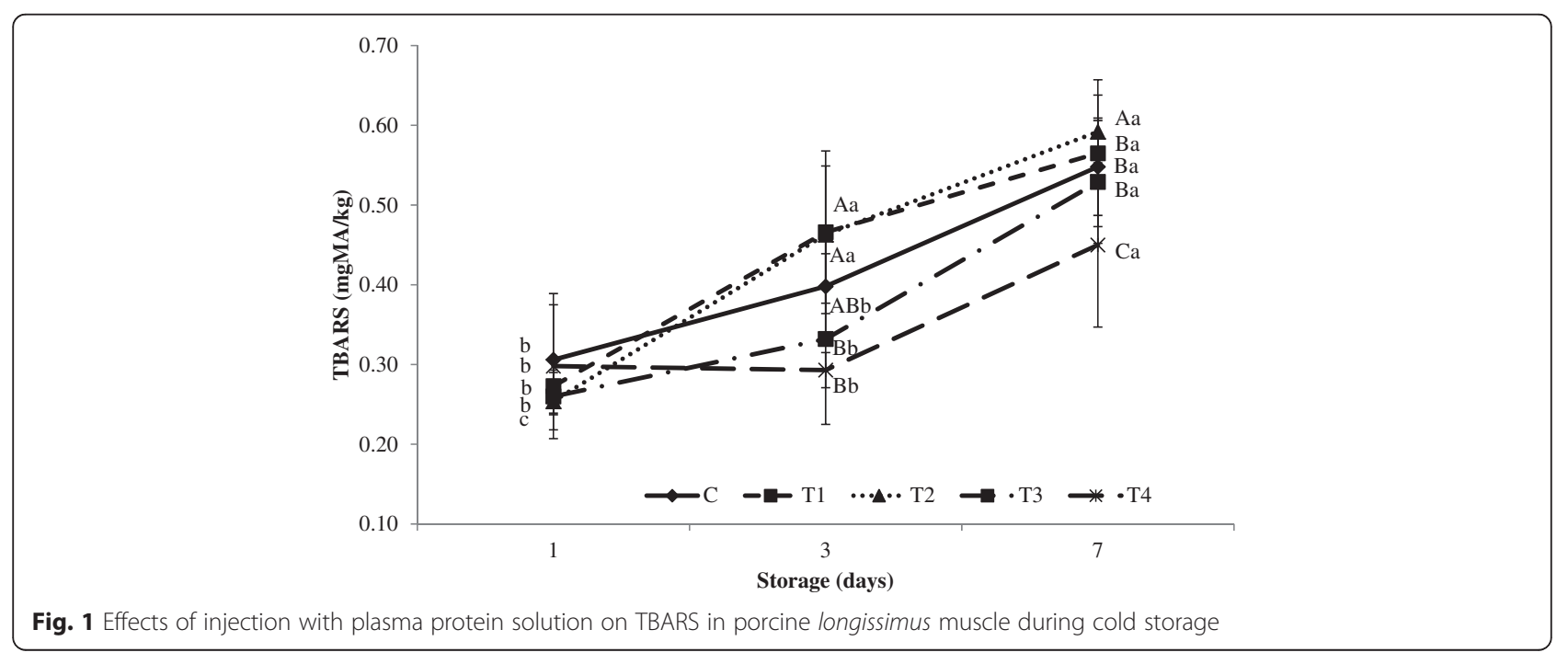


muscle injected with hydrolysis plasma proteins may also be due to the antioxidant characteristics of milk powder [48, 49].

Hydrolysis and non-hydrolysis plasma protein solutions showed increased antioxidant activities during cold storage. According to Faustman and Cassens [32], lipid oxidation and myoglobin oxidation are closely related in meat an increase in one result in a similar increase in the other. This pattern was thought to be related to the direct oxidation of $\mathrm{Mb}$ or the destruction of Mb-reducing systems by free radicals generated during lipid oxidation. Guo et al. [50] reported that, in their study, the low molecular weight fraction $(<1 \mathrm{k})$ of protease $\mathrm{N}$ hydrolysate of royal jelly proteins had the greatest antioxidant activity. Further, Park et al. [51] reported strong antioxidant activity in hydrolysate from egg yolk protein.

\section{Conclusions}

Proximate composition of the injection of pre-rigor porcine longissimus lumborum muscle with non-hydrolysis and hydrolysis plasma protein showed higher moisture and lower protein contents than the control. The $\mathrm{pH}$ and lightness showed no differences between control and T4, whereas significantly higher redness and yellowness were found in T4. Hydrolysis plasma protein significantly decreased MetMb content during cold storage. Shear force was significantly lower in T4 than control and other treatments. The lower TBARS was observed in the porcine longissimus muscle injected with nonhydrolysis and hydrolysis plasma protein solutions compared to the control.

The main findings of our study are that (1) injection of pre-rigor porcine longissimus lumborum muscle with non-hydrolysis and hydrolysis plasma proteins improves pork quality and (2) longissimus lumborum muscle $\mathrm{pH}$, meat color, tenderness, protein solubility, and lipid oxidation in pork loin are directly affected by the concentrations of injected non-hydrolysis and hydrolysis plasma proteins. Thus, our study clearly highlights the potential use of hydrolysis plasma proteins in improving the tenderness of pork and increasing storage life.

\section{Competing interests}

The authors declare that they have no competing interests.

\section{Authors' contributions}

HW and JK performed all experiments and data analyses. The manuscript of this article was written by HW and JK and both equally contributed to this research. HS supervised this research and revised the manuscript. All authors carefully read and approved the final manuscript and agree to publish in this form.

\section{Acknowledgments}

This research was supported (Project No.113027033) by High Value-added Food Technology Development Program, Ministry of Agriculture, Food and Rural Affairs.

\section{Author details}

'National Institute of Animal Science, RDA, Wanju 55365, South Korea. ${ }^{2}$ Division of Applied Life Science Graduate School (BK21 plus), Institute of Agriculture and Life Science, Gyeongsang National University, Jinju 52828, South Korea.

Received: 24 November 2015 Accepted: 22 July 2016

Published online: 17 August 2016

\section{References}

1. Bjerklie S. Pumped pork: Palliate or parody?. Meat Processing 1998. p. 94.

2. Rust RE. Marketing opportunities for enhanced fresh pork. Meat Int. 1998;8:36-9.

3. Detienne NA, Wicker L. Sodium chloride and tripolyphosphate effects on physical and quality characteristics on injected pork loins. J Food Sci. 1999; 64:1042-7.

4. Vote DJ, Platter WJ, Tatum JD, Schmidt GR, Belk KE, Smith GC, Speer NC Injection of beef strip loins with solutions containing sodium tripolyphosphate, sodium lactate, and sodium chloride to enhance palatability. J Anim Sci. 2000;78:952-7.

5. Murphy MA, Zerby HN. Prerigor infusion of lamb with sodium chloride, phosphate and dextrose solutions to improve tenderness. Meat Sci. 2004;66: 343-9.

6. Offer $G$, Trinick J. On the mechanism of water holding in meat; the swelling and shrinking of myofibrils. Meat Sci. 1983;8:245-81.

7. Sheard PR, Nute GR, Richardson RI, Perry A, Taylor AA. Injection of water and polyphosphate into pork to improve juiciness and tenderness after cooking. Meat Sci. 1999;51:371-6.

8. Killefer J. Effect of enhancement of pork and beef on post mortem events. Proceed. 59th Reciprocal Meats Conference, Lexington, KY;2004.

9. Streitel RH, Ockerman HW, Cahill VR. Maintenance of beef tenderness by inhibition of rigor mortis. J Food Sci. 1977;42:583-5.

10. Smith LA, Simmons SL, McKeith FK, Bechtel PJ, Brady PL. Effects of sodium tripolyphosphate on physical and sensory properties of beef and pork roasts. J Food Sci. 1984;49:1636-7.

11. Robbins K, Jensen J, Ryan KJ, Homco-Ryan C, McKeith FK, Brewer MS. Enhancement effects on sensory and retail display characteristics of beef rounds. J Muscle Foods. 2002:13:279-88.

12. de Gonzalez MT N, Boleman RM, Miller RK, Keeton JT, Rhee KS. Antioxidant properties of dried plum ingredients in raw and precooked pork sausage. J Food Sci. 2008;73:H63-71.

13. Ahn J, Gruen IU, Fernando LN. Antioxidant properties of natural plant extracts containing polyphenolic compounds in cooked ground beef. J Food Sci. 2002; 67:1364-9.

14. Li B, Chen F, Wang X, Ji B, Wu Y. Isolation and identification of antioxidative peptides from porcine collagen hydrolysate by conseutive chromatography and electrospray ionization-mass spectrometry. Food Chem. 2007;102:1135-43.

15. Salgado PR, Fernández GB, Drago SR, Mauri AN. Addition of bovine plasma hydrolysates improves the antioxidant properties of soybean and sunflower protein-based films. Food Hydrocol. 2011;25:1433-40.

16. Alder-Nissen J. Some fundamental aspects of food protein hydrolysis. In: Enzymic hydrolysis of food proteins. New York: Elsevier Applied Science Publishers; 1986. p. 172-200.

17. AOAC. Official methods of analysis. 17th ed. Gaithersburg, MD: Association of Official Analytical Chemists; 2000.

18. Folch J, Lees M, Sloane-Stanley GH. A simple method for the isolation and purification of total lipid from animal tissues. J Biol Chem. 1957;26:497-509.

19. Boles JA, Swan JE. Effect of post-slaughter processing and freezing on the functionality of hot-boned meat from young bull. Meat Sci. 1996;44:11-8.

20. Krzywicki K. The determination of haem pigments in meat. Meat Sci. 1982;7: 29-36.

21. Helander EAS. Influence of exercise and restricted activity on the protein composition of skeletal muscle. Bochem J. 1961;78:478-82.

22. Buege JA, Aust SD. Microsomal lipid peroxidation. Methods Enzymol. 1978; 52:302-10.

23. SAS 9.0. The SAS program for window. Cary, NC: The SAS Institute, Inc. 2009

24. Sindelar JJ, Prochaska F, Britt J, Smith GL, Miller RK, Templeman R, Osburn WN. Strategies to eliminate atypical flavours and aromas in sow loins. 1. Optimization of sodium tripolyphosphate, sodium bicarbonate, and injection level. Meat Sci. 2003;65:1211-22. 
25. Wynveen EJ, Bowker AL, Grant AL, Lamkey JM, Fennewalk KJ, Henson L, Gerrard DE. Pork quality is affected by early postmortem phosphate and bicarbonate injection. J Food Sci. 2001;66:886-91.

26. Marcos B, Kerry JP, Mullen AM. High pressure induced changes on sarcoplasmic protein fraction and quality indicators. Meat Sci. 2010;85: 115-20.

27. Owens CM, Hirschler EM, McKee SR, Martinez-Dawson R, Sams AR. The characterization and incidence of pale, soft, exudative turkey meat in a commercial plant. Poul Sci. 2000;79:553-8.

28. Chaijan M, Benjakul S, Visessanguan W, Faustman C. Characteristics and ge properties of muscles from sardine (Sardinella gibbosa) and mackerel (Rastrelliger kanagurta) caught in Thailand. Food Res Int. 2004;37:1021-30.

29. Kauffman RG, van Laack RL, Russell RL, Pospiech E, Cornelius CA, Suckow CE, et al. Can pale, soft, exudative pork be prevented by postmortem sodium bicarbonate injection? J Anim Sci. 1998;76:3010-5.

30. Warner RD, Kauffman RG, Greaser ML. Muscle protein changes postmortem in relation to pork quality traits. Meat Sci. 1997;45:339-52.

31. Joo ST, Kauffman RG, Kim BC, Park GB. The relationship of sarcoplasmic and myofibrillar protein solubility to colour and water-holding capacity in porcine longissimus muscle. Meat Sci. 1999;52:291-7.

32. Faustman C, Cassens RG. The biochemical basis for discoloration in fresh meat: a review. J Muscle Foods. 1990;1:217-43.

33. Mancini RA, Hunt MC. Current research in meat color. Meat Sci. 2005:71:100-21.

34. Brewer MS, Zhu LG, Bidner B, Meisinger DJ, McKeith FK. Measuring pork color: effects of bloom time, muscle, $\mathrm{pH}$ and relationship to instrumental parameters. Meat Sci. 2001;57:169-76.

35. Lindahl G, Lundstrom K, Tornberg E. Contribution of pigment content, myoglobin forms and internal reflectance to the colour of pork loin and ham from pure breed pigs. Meat Sci. 2001;59:141-51.

36. McKenna DR, Mies PD, Baird BE, Pfeiffer KD, Ellebracht JW, Savell JW Biochemical and physical factors affecting discoloration characteristics of 19 bovine muscles. Meat Sci. 2005;70:665-82.

37. Suman SP, Faustman C, Stamer SL, Liebler DC. Proteomics of lipid oxidationinduced oxidation of porcine and bovine oxymyoglobins. Proteomics. 2007; 7:628-40.

38. Renerre M. Factors involved in the discoloration of beef meat. J Food Sci Technol. 1990;25:613-30

39. Renerre M, Labas R. Biochemical factors influencing metmyoglobin formation in beef muscles. Meat Sci. 1987;19:151-65.

40. Carlez A, Veciana-Nogues T, Cheftel JC. Changes in colour and myoglobin of minced beef meat due to high pressure processing. LWT-Food Sci Technol. 1995:28:528-38.

41. Choi YM, Ryu YC, Lee SH, Go GW, Shin HG, Kim KH, Rhee MS, Kim BC. Effects of supercritical carbon dioxide treatment for sterilization purpose on meat quality of porcine longissimus dorsi muscle. LWT-Food Sci Technol. 2008;41:317-22.

42. Farouk MM, Wieliczko K, Lim R, Turnwald S, MacDonald GA. Cooked sausage batter cohesiveness as affected by sarcoplasmic proteins. Meat Sci. 2002;61: 85-90.

43. Kim YS, Yongsawatdigul J, Park JW, Thawornchinsombut S. Characteristics of sarcoplasmic proteins and their interaction with myofibrillar proteins. J Food Biochem. 2005;29:517-32.

44. Marta G, Guerrero L, Sarraga C. The effect of meat quality, salt and ageing time on biochemical parameters of dry cured Longissimus dorsi muscle. Meat Sci. 1999:51:329-37.

45. Lawrence TE, Dikeman ME, Hunt MC, Kastner CL, Johnson DE. Effects of calcium salts on beef longissimus quality. Meat Sci. 2003;64:299-308.

46. Baublits RT, Pohlman FW, Brown Jr AH, Yancey EJ, Johnson ZB, Dias-Morse P. Solution enhancement and post-enhancement storage effects on the quality, sensory, and retail display characteristics of beef triceps brachii muscles. J Food Sci. 2006:71:S91-6.

47. Yasui T, Sakanishi M, Hashmoto Y. Phosphate effect on meat, effect of inorganic polyphosphates on solubility and extractability of myosin B. J Agri Food Chem. 1964;12:392-9.
48. Cornforth DP. West EM Evaluation of the antioxidant effects of milk mineral in cooked beef, pork, and turkey. J Food Sci. 2002;67:615-8.

49. Vasavada MN, Cornforth DP. Evaluation of milk mineral antioxidant activity in beef meatballs and nitrite-cured sausage. J Food Sci. 2005;70:C250-3.

50. Guo H, Kouzuma Y, Yonekura M. Structures and properties of antioxidative peptides derived from royal jelly protein. Food Chem. 2009;113:238-45.

51. Park PJ, Jung WK, Nam KS, Shahidi F, Kim SK. Purification and characterization of antioxidative peptides from protein hydrolysate of lecithin free egg yolk. J Am Oil Chem Soc. 2001;78:651-6.

\section{Submit your next manuscript to BioMed Central and we will help you at every step:}

- We accept pre-submission inquiries

- Our selector tool helps you to find the most relevant journal

- We provide round the clock customer support

- Convenient online submission

- Thorough peer review

- Inclusion in PubMed and all major indexing services

- Maximum visibility for your research

Submit your manuscript at www.biomedcentral.com/submit
) Biomed Central 